\title{
Transformations in the gardens and landscapes of the historical Traituba's Farm ${ }^{(1)}$
}

\author{
CECILIA SOUZA GONTIJO GARCIA(2)*; PATRÍCIA DUARTE DE OLIVEIRA PAIVA ${ }^{(2)}$; \\ SCHIRLEY FÁTIMA NOGUEIRA DA SILVA CAVALCANTE ALVES(3); MARIEL DE CARVALHO RAFAEL SALGADO(2)
}

\begin{abstract}
The historic garden should be considered one that has cultural significance, being not only the squares and public gardens, but also its first manifests found in the form of orchard garden and vegetable garden in the historic farms of Brazil. Traituba's Farm located in southern Minas Gerais, on the Royal Road route, is considered an important historical farm that emerged in the eighteenth century during the settlement process of this region. It was in the same period, that current rural landscape from southern Minas Gerais, composed of several other historic farms and the historic rural gardens began their formation process. The aim of this study was to conduct a historical and cultural rescue of the gardens and landscapes of the Traituba's Farm. With this rescue, characterize and analyze their landscapes in their different ages, as well as identify and understand the main morphological changes of its gardens included in the architectural complex of the farm. This study focused on the period between 1725 and 2013 . To trace the historical, cultural and landscape evolution, it was made researches through site visits, interviews, bibliographic and iconographic research, always following the principles of studies of historic gardens. Traituba's Farm since its formation was always a region icon, because of its wealth, power and intense trade. Its landscapes have undergone many changes and are characterized initially as a pastoral model, then the bucolic and picturesque style, after the construction of the new farmhouse. With the decline of its activities, decades later the model that remained was the picturesque and pastoral as its origin. For a long time, its gardens were presented as orchards gardens and vegetable gardens with utilitarian characteristics, influenced by the Portuguese culture. Just in 1950s the front yard received a significant intervention and new species were planted where that the design can be seen until today. The significance of this paper is due to the historical value of the Traituba's Farm, the magnificence of its architectural ensemble, peculiarity of gardens and landscapes, and great cultural representation in the region.
\end{abstract}

Keywords: history, historical gardens, Royal Road, bucolic landscape, picturesque landscape.

\section{RESUMO}

Transformações nos jardins e paisagens da histórica Fazenda Traituba

O jardim histórico deve ser considerado aquele que possui significado cultural, sendo não apenas as praças e os jardins públicos, mas também seus primeiros manifestos, encontrados em forma de jardim-pomar e jardim-horta nas fazendas históricas do Brasil. A Fazenda Traituba localizada no sul Minas Gerais, na rota da Estrada Real, é considerada uma importante fazenda histórica que surgiu no século XVIII durante o processo de povoamento dessa região. Foi neste mesmo período, que a atual paisagem rural sul mineira, compostas de outras diversas fazendas históricas e seus jardins rurais históricos, iniciou seu processo de formação. O objetivo deste estudo foi realizar um resgate histórico e cultural dos jardins e paisagens da Fazenda Traituba. Com este resgate, caracterizar e analisar suas paisagens em suas diferentes épocas, bem como identificar e compreender as principais alterações morfológicas de seus jardins incluídos no complexo arquitetônico da fazenda. Este estudo focalizou o período entre 1725 e 2013. Para traçar a evolução histórica, cultural e paisagística, realizou-se pesquisas através de visitas de campo, entrevistas, pesquisa bibliográfica e iconográfica, sempre seguindo os princípios de estudos de jardins históricos. A Fazenda Traituba, desde sua formação, sempre foi um ícone da região, devido a sua riqueza, poder e intenso comércio. As suas paisagens sofreram diversas modificações, caracterizando-se inicialmente como modelo pastoral, em seguida, pelo modelo bucólico e pitoresco, após a construção da nova sede. Com o declínio de suas atividades, décadas mais tarde, o modelo que permaneceu foi o pitoresco e o pastoral como de sua origem. Seus jardins apresentaram-se durante muito tempo como jardins-horta e jardins-pomar com características utilitárias, influenciado pela cultura portuguesa. Foi apenas a partir da década de 1950 que o jardim de entrada recebeu uma intervenção onde o traçado pode ser observado até hoje. A importância deste trabalho se deve ao grande valor histórico da Fazenda Traituba, da imponência de seu conjunto arquitetônico, da peculiaridade de seus jardins e paisagens, e de sua grande representatividade cultural na região.

Palavras chave: história, jardins históricos, Estrada Real, paisagem bucólica, paisagem pitoresca

DOI: http://dx.doi.org/10.14295/oh.v23i1.953

(1) Received in 30/08/2016 and accepted in 03/12/2016

(2) Universidade Federal de Lavras (UFLA), Departamento de Agricultura, Lavras-MG, Brazil. *autor correspondente: cissasgg@hotmail.com

(3) Centro Universitário de Lavras (UniLavras), Lavras-MG, Brazil 


\section{INTRODUCTION}

Areas that have cultural significance with ability to strengthen the memory and identity of a society should be considered as historical gardens (ANDRADE, 2008). They are considered not only the squares and public gardens found in the cities, but also should give importance to their first manifest, which are found in the orchard garden and vegetable garden form of the historic farms of Brazil (DELPHIM, 2005). The name of the space as historic garden can also help in the conservation of sites of historical, environmental and cultural interest (ANGELIS and ANGELIS NETO, 2004).

In the southern region of Minas Gerais there are several historic farms of the eighteenth century, which emerged after the settlement process in the region, and have always been present in the history and culture of the population. The settlement of the southern region of Minas Gerais began when Paulistas excursions invaded and braved these areas (BRUNO, 1967, HOLANDA, 1995). After the first indications of gold in the territory, many other Paulistas, local settlers and Portuguese people also went to Minas Gerais (BRUNO 1967, HOLANDA, 1995). This gold exploration cycle occurred throughout the eighteenth century, being responsible for the formation of numerous population centers in the region (BRUNO, 1967), in addition to the ranches and landing sites, considered points of support to the pioneers (VASCONCELLOS, 1977).

At that time, agriculture began in Minas Gerais territory, included the method defined as "fire and hoe" a process that was overthrowing, burning, cleaning, sowing and reaping (BOXER, 1963). These were agricultural practices that formed the current Minas Gerais pastoral landscape, very different from the existing landscape in the eighteenth century in the district of Rio das Mortes, political demarcation established in Minas in 1714 referred to the southern region of the state.

Still in the eighteenth century, many people considered agricultural activities the most profitable compared to mining, as there was great demand for food in relation to the supply in the region and the numerous travelers needed to replenish. Thus, along the roads, quickly formed many farms and small poultry farms (BOXER, 1963). The demand by the first land grants ${ }^{(4)}$ concessions also occurred in that period, further stimulating the emergence of these farms in the Rio Grande region, part of the district of Rio das Mortes (AMATO, 1996). Traituba's Farm inserted in the old Royal Road route is an example of these farms formed at this time in the region. In that road, it was much traveled since the seventeenth century to the nineteenth century by miners and merchants (CARVALHO, 2010). It was in this period that the current southern Minas Gerais landscape, composed of several historic farms, began its formation process. In the nineteenth century, considering the records of the French traveler Saint-Hilaire (1938), who passed in the region in 1822, the lands of the district Rio das Mortes were famous for its agricultural qualities and therefore highly sought after.

The preservation and raising a more detailed study are fundamental to the constitution and the historical and cultural national rescue, since many facts and important decisions were taken in these remarkable farms. It is exactly the gardens of historic Minas Gerais farms, the site where it can observe the Portuguese influence to link the garden to the vegetable garden and to the orchard (DELPHIM, 2005).

In Brazil, the study of its historic gardens is recent, but noted for its importance to the better definition of the history of the Brazilian landscape, and further this work should be used as a data source to justify the preservation and maintenance of these important historical sites of national culture (DELPHIM, 2006; SILVA et al, 2008; ALVES et al., 2010; GARCIA et al., 2011; PAIVA and NASCIMENTO, 2012; ALVES et al., 2013; ALVES et al., 2015; JUSTE and PAIVA, 2015).

The aim of this study was to conduct a historical and cultural rescue of the gardens and landscapes of the Traituba's Farm. With this rescue, characterize and analyze their landscapes in their different ages, as well as identify and understand the main morphological changes of its gardens included in the architectural complex of the farm. This study focused on the period between 1725 and 2013 . To trace the historical, cultural and landscape evolution, it was made researches through site visits, interviews, bibliographic and iconographic research, always following the principles of studies of historic gardens, and identify their representation in the collective unconscious of the inhabitants of the region. For this it was necessary deepen the knowledge in the history and the formation of their farms in the post-discovery of gold period of this area in Minas Gerais state.

\section{METHODOLOGY}

The study was centralized in the period from 1725 to 2013. Traituba's Farm was determined as study object due to its great historical and cultural value in the region where it is located, in the grandeur of its architectural ensemble, and be located along the old way of the Royal Road, presenting a great tourist potential.

The theoretical bases to trace the historical, cultural and landscape evolution of Traituba's Farm were an interface among the principles of Delphim (2005), Lassus (1994) and Luginbuhl (2006) as already used in other studies of Brazilian historic gardens (ALVES et al., 2015; JUSTE e PAIVA, 2015).

Luginbuhl (2006) in his subjective analysis does not provide a quantitative assessment. This assessment makes clear aesthetic, phenomenological or symbolic values. This method is based on the assumption that the landscapes and their representations have values that are assigned by their populations, artists or by writers who marked the aesthetic or symbolic attributes in their works.

\footnotetext{
${ }^{(4)}$ Land grants were demarcated land with an area of three (3) square leagues. One (1) square league is approximately 4.356 hectares
} 
The inventive analysis of Lassus (1994) makes it possible to identify and analyze the practices and physical evolution processes from one place when it made an interpretation of natural, heritage and social data of the same. This analysis enables us to discern what would be most appropriate in the specific relation between the place and its social practices.

Delphim (2005) collaborates with technical guidance on conservation and historic gardens preservation, considering the unique aspects of each, so that each site has a particular evolution and own solutions.

The first execution phase of this work consists of field research to identify the historical significance of Traituba's Farm. The research centered its interest in the morphological transformation of the space occupied by the architectural group $>$ farmhouse for its gardens and landscapes of its surroundings, as well as social representation of these locations in the collective unconscious of the population of the farm and the region throughout its history.

In addition, a research was made with documentary, literature, archaeological, interviews, iconographic surveys including a literature review of the history cities of Cruzilia and Carrancas and settlement process in the region. These surveys were conducted in the Municipal Library Castro Alves de Carrancas, in the Regional Museum of Mangalarga Marchador in Cruzília - MG.

The iconographic survey shows great importance in this work, helping to elucidate the transformations of these spaces: sometimes placing facts recorded bibliographically and other revealing events recorded by images only. The collection was found, mostly with the former owner of the farm, D. Alice Aguiar Junqueira or even in the Traituba's Farm. Architectural projects and illustrations from different phases of architectural and landscape structure the farmhouse were also analyzed.

The field research also included informal interviews with the owners and former owners, family relatives of Junqueira, who have lived in the region of the farm and also reports of employees who were born and grown up on the farm.

The second phase of this research is to carry out a survey of the current state of the farmhouse, seeking to identify its gardens, landscapes and representative spaces.

The third and final stage was to compile this data and organize them in the historical process of this area occupation, evoking the evolution of the local use, as well as the space appropriation.

\section{RESULTS AND DISCUSSION}

\section{Agricultural landscape formation}

After the gold discovery in Minas Gerais, throughout the eighteenth century, many villages were formed and, along the roads linking these auriferous regions to the court, there were several farms (BRUNO, 1967; VASCONCELLOS,
1977; HOLANDA, 1995). In these farms are planted fields, mainly corn, pumpkin, beans and, in some cases, potato (BOXER, 1963).

The first species cultivated and processed in the Rio Grande region were: sugarcane, cotton, tobacco, corn, beans, rice and cassava. With this production was made, a cornmeal cake, cookies and crackers, bread, sweet of cane sugar called Rapadura and alcoholic beverage made of sugar cane called Cachaça, etc. These products were consumed on farms and the surplus sold. Swine, chicken, sheep and donkeys were present in the farms' culture of this region. With cotton and wool were produced fabrics in rustic home looms. With the swine creation was taken fat and the meat was salted, smoked or kept in pork fat brasses for future consumption or even for marketing. The dairy farming was intended to the production of cheese and butter which were also sold and consumed in other regions of the country. Many fruit trees are found until today in these farms forming large orchards. With these fruits, always make sweets, jams and jellies (AMATO, 1996).

These farms form a subsistence system where everything was consumed was produced in the site, requiring only salt and kerosene (AMATO, 1996). The movement generated by slaves, cattle dealer and owners of farms in the context of this diversity of crops and livestock, created a bucolic landscape that became peculiar in that region at that time, characterizing their farms.

In the nineteenth century the lands of the Rio das Mortes region were much sought after, famous for its agricultural qualities. The French traveler Saint-Hilaire (1938) made some reports when passing through the region on his second trip to Rio de Janeiro, Minas Gerais and São Paulo:

\footnotetext{
.. the cattle around Rio Grande area has justified fame, thanks to the size and strength. Fed on great pastures, cows give milk almost as rich as our mountains. With the milk makes lot of cheese sent to Rio de Janeiro ... (SAINT-HILAIRE, 1822).
}

Therefore, like Traituba's Farm, many other farms are formed in this region in the seventeenth and eighteenth centuries. Only a few historic farms still exist today in the south of Minas Gerais, and the main reasons for this are usually related to the bankruptcy of families, poor maintenance, sales to third parties and demolition for sale of materials. Currently, when traveling through this area it can see the ruins of some old farms (GARCIA et al., 2014). The existence of these farms can be proven by records of old maps, travelers' reports, documents and reports of the local population (CRUZ, 2010).

\section{Traituba's Farm and its landscapes}

Currently, the land and the Traituba's Farm (Figure 1) are located in the municipality of Cruzilia in the southern region of Minas Gerais, where beginning the state's colonization and belonged to the district of Rio das Mortes. 


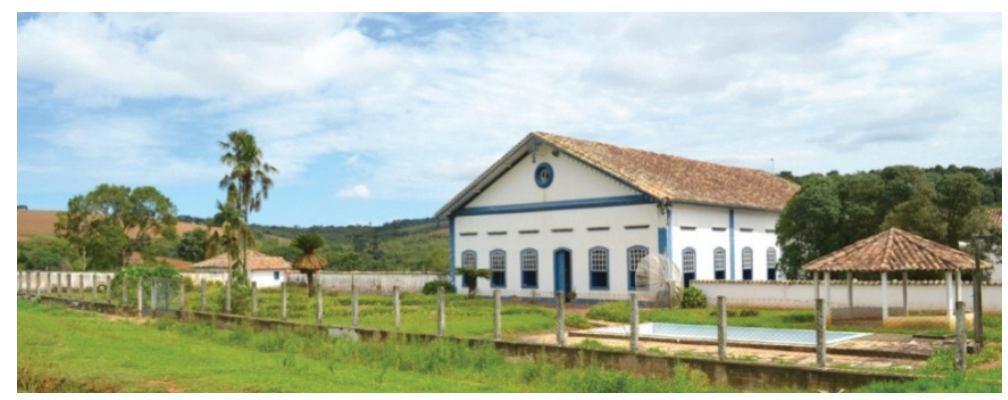

Figure 1. Traituba's Farm, Cruzília-MG. Date: 2013. Source: Garcia

Traituba's Farm has always been owned by the Junqueira family, descendants of Portuguese. However, in 2009, it was sold by former owners to a group of entrepreneurs who nowadays manages this property (GARCIA, 2013).

Traditional Junqueira's family came up with the Portuguese João Francisco Junqueira, who settled as a farmer in Rio das Mortes region in 1763, when he received a land grant from Campo Alegre. In 1810 he bought part of the land grant of Favacho and Angahy that were neighbors of Campo Alegre, forming a vast latifundium. This was subdivided into several farmhouses and ranches, emerging the different farms that were distributed to their children, among which there is the Traituba.

The first record found of the Traituba's Ranch existence was a document from the French traveler SaintHilaire that passed through the lands of the property on his second trip to Minas Gerais. Traituba's Farm has always been known to receive travelers and cattle dealer, even having a specific home for this function (GARCIA et al., 2014).

The eldest daughter of João Francisco Junqueira married in 1780 and took up residence the former Traituba's Ranch farmhouse (MATTOS, 2004). In 1822, the couple received the Saint-Hilaire traveler who made the following description of the farm's day-to-day:

Traituba's Ranch. March 2 (1822), 4 leagues.

As previously said, shut every night the calves in a stockyard and cows come close by themselves to the farm. In the dawn make them enter in the yard where they are milked by black men and women. (...) SAINT-HILAIRE (1822)
Note that the main agricultural activity of this time on the farm was the creation of dairy cattle. On the farm was produced butter and cheese that were sent to Rio de Janeiro by cattle dealer, activity that lasted until the mid-twentieth century (GARCIA et al, 2014). Saint-Hilaire (1938) draws attention to the fame of good cattle that was created in the region. The pastoral landscape ${ }^{(5)}$ of this farm caught the attention of this traveler.

Since Greek Arcadia, European culture considers beautiful landscapes composed by animals scattered in their pastures (LUGINBHUL, 1989).

The new farmhouse was built from 1827 to 1831 by Colonel João Pedro Diniz Junqueira, the family patriarch's grandson (MATTOS, 2004). The Emperor D. Pedro I maintained friendly relationship with this colonel.

Some people of the Junqueira's family mention that $D$. Pedro I went to the farm sometimes to practice one of his main hobbies, hunts (GARCIA, et al., 2014). But other authors such as Lopes (2012), affirm that the oldest Traituba's Ranch were only a few members of the court and not the specific Emperor. The illustrious presence of D. Pedro I on the farm is a doubt, but the fact is, at one point, Colonel João Pedro Diniz Junqueira decided to build a house worthy to receive the Emperor and his entire entourage.

The house is considered a monumental work, fashionable, and one of the largest in the region since that time. Hundreds of farm slaves worked in its construction (GARCIA and SALGADO, 2013). The farmhouse complex, bordered by a large wall, it was composed of the Big House, guest house and the slave quarters, besides the four yards, one in front, two side and one in the back (Figure 2).

\footnotetext{
(5) The history of painting created its models of landscape representations: pastoral, bucolic, picturesque, sublime and panoramic. The pastoral landscape is considered to be one that makes mention of the antiquity novels, describing on the lives of shepherds, as the bucolic landscape concerns the daily life of the peasants, and the picturesque is defined as one that is worthy of being painted (LUGINBHUL, 1989).
} 


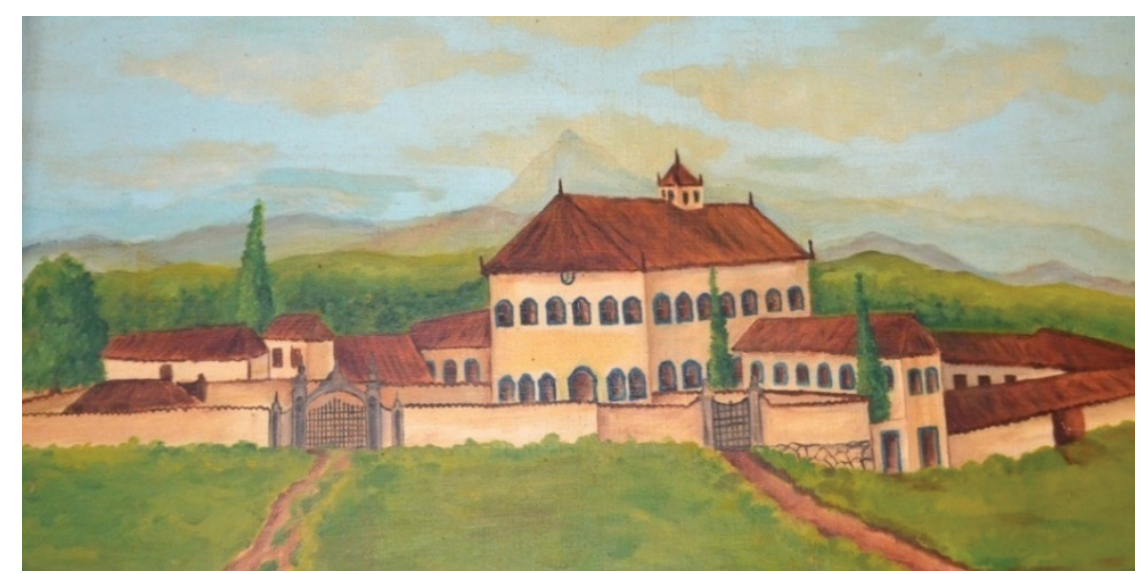

Figure 2. Big House in the nineteenth century - Oil painting by Nilza Meirelles (1960). Source: Traituba's Farm private collection.

It's possible to realize that João Pedro Diniz Junqueira imagined his work as a great fortress of two floors, surrounded by walls and decorated with a viewpoint, demonstrating its power. His seigniorial feature expressed nobility and power, features that Junqueira's family has always shown in their history (GARCIA et al., 2014).
In the large front yard (1) (Figure 3) worked the farm trade, which has always been very active and busy, relying primarily on the buying and selling of animals and slaves (GARCIA and PAIVA, 2012). The slave quarters of Traituba's Farm, located in the backyard (4), it was not as precarious as rule, allowing the slaves' families to live separated from the group.

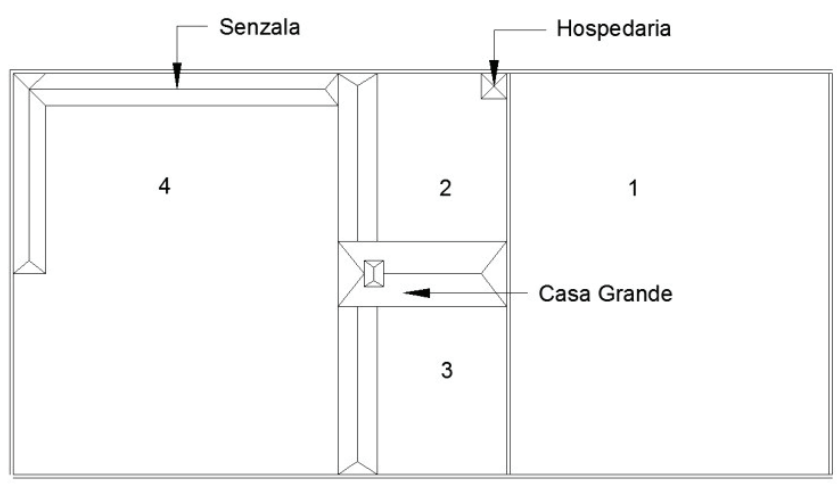

Figure 3. Sketching the farmhouse complex of Traituba's Farm. Source: Garcia (2014)

The chickens and pigs stayed loose during the day, on the side of the house, in the yard 3 (Figure 3 ). The lateral yard 2 was sale access area, is located under the farmhouse with two warehouses, one for salt and other starch (Figure 4). The guest house of travelers was a small building located inside this yard, but with the access door facing the trade yard (1). In this courtyard there was also a small garden, called by the Junqueira's family descendants as "Old Garden". This also was used later as stockyard for deer that were quarantined and after this period loose them for hunting, main hobbie of Junqueira's family. 

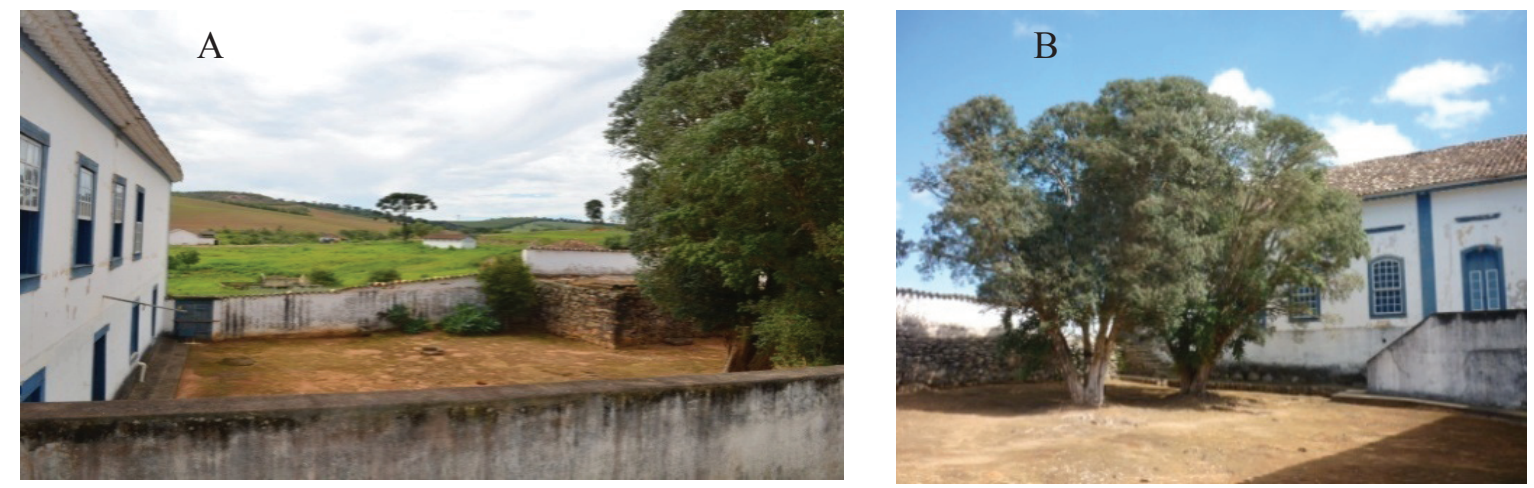

Figure 4. Left yard, Old Garden; Stockyard for deer (A, B).

Structural basis of old guest house (A). Date: 2013. Source: Garcia

The stockyard and orchard are located outside the walls. Alongside this orchard was planted and cultivated a large vegetable garden, called by the family as old garden. Even being in the nineteenth century, this presence of the orchard and the vegetable garden around the farmhouse refers to the gardens of medieval European monasteries that also had utility trait in detriment of flowerbeds (PAIVA, 2008).

The Traituba's Farm landscape, before Big House construction, was formed by a ranch, inserted in large pastures, divided by valleys, small rivers and hills, referring to the pastoral model. This landscape has undergone a major intervention when the new farmhouse was built. What once refers to the quiet pastoral landscapes turned into a very busy place, because of the agricultural production and trade movement that settled there. This change created a new farm landscape model, the bucolic. In this context, it has even the magnificence of the building of the Big House complex that generated references to the picturesque landscape.

The bucolic model lasted for about 150 years, a period of intense activity on the farm. At the end of the twentieth century with the activities decline, what prevailed was the picturesque landscape (Figure 2) consists of its architectural complex, set in large pastures, which also alluded to the pastoral model.

\section{Big House and its landscapes transformations}

In 1902, it was carried out a major renovation in the Big House, when it was demolished the second floor and removal its viewpoint. After the slavery abolition, the slave quarters was turned off, turning into stockyards and farm implements deposits. The yard 4 (Figure 2) that housed a pillory before, turned into a waiting stockyard for cows would be milked and pasture for their calves.

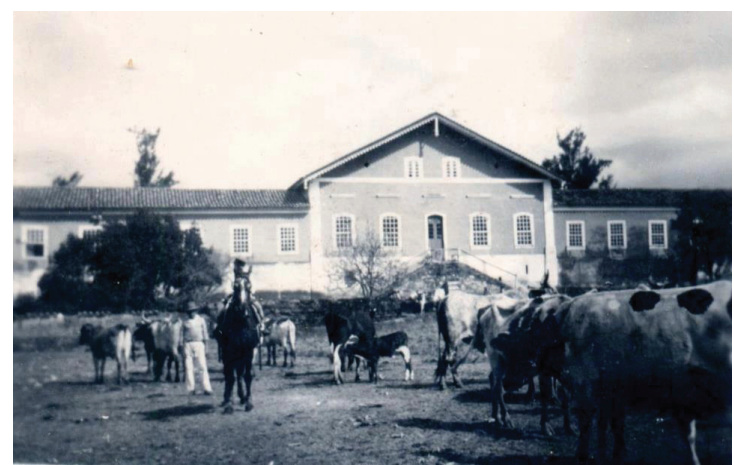

Figure 5. Big House without the second deck and viewpoint. Cows on the lower yard, stockyard waiting probable date: before 1953. Source: Private collection of Junqueira's family

With the slave quarters deactivation, many houses were built for former slaves who became employees of the farm and came to be called settlers. From this cluster was formed a small village, having even some streets named. In addition, the front yard of the house, became the space dedicated to trade in animals, especially horses Mangalarga Marchador breed developed in the Junqueira's family lands. Over time, other changes were occurring as the construction of the first butter factory in
Minas Gerais, electricity power plant, pigsties, stockyards and bays outside the farmhouse walls (GARCIA and SALGADO, 2013).

The landscape before formed by a large number of people living within the farmhouse walls changed, decentralizing this intense movement after the work shift, when the settlers returned to their homes. Cultural events that occur before in the slave quarters of the yard were moved to this small village. 
A second reform took place in 1953, where part of the side services was demolished and its interior has been restructured. The old slave quarters turned into stockyards was demolished leaving only the warehouses in the backyard 4 (Figure 6). This yard ceased to house the cows and calves, their trees were cut and the ground was leveled and it was transformed into a horse exhibition space. In this yard was also constructed a rustic kiosk for buyers of Mangalarga Marchador horses could sit and watch them. In the same place was built a new service area and kitchen. Just below this place, still in the same yard, a small area was fenced with bamboo and wire where was cultivated flowers and ornamental plants, called by the owners - greenhouse.

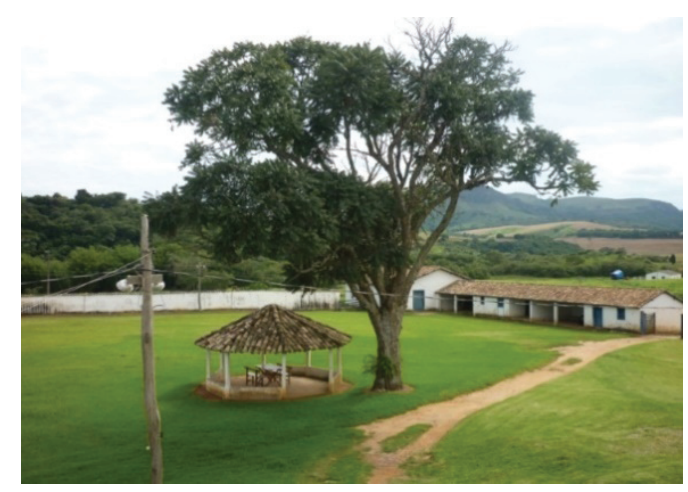

Figure 6. The yard. Old Slave quarters to the right and kiosk for horse buyers (former pillory). Date: 2013 Source: Garcia

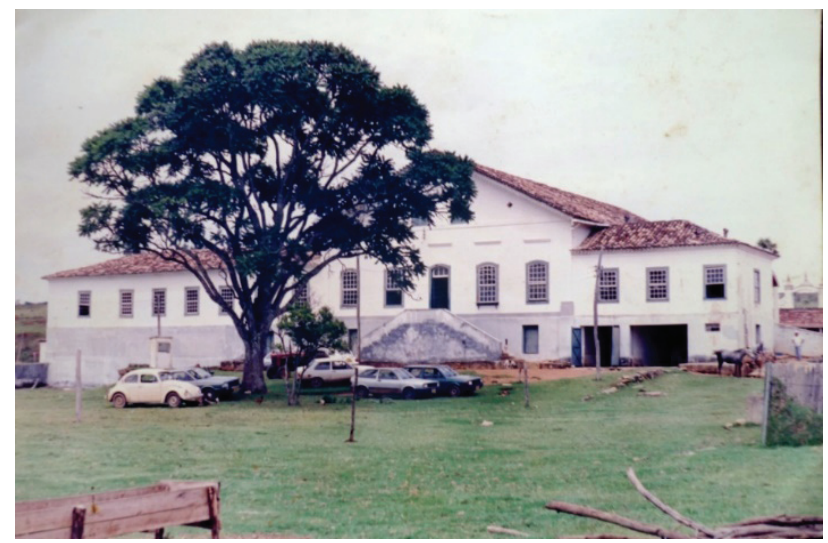

Figure 7. Photo from 1960s, detail of a greenhouse to the right corner of the photo. Source: Private collection of Junqueira's family

Everything indicates that the front yard (1) housed around the farmhouse, since the first reform in 1902, a vegetable garden and a garden. Already in 1953, the vegetable garden was removed and the garden was expanded. The travelers' house, located in the side yard 2 , was also demolished in the same reform, and the "Old garden" of this yard was transformed into stockyards for deer destined to hunting. In 1985, the farm received some repairs and started receiving many visitors, which made its owner decided to turn it into Hotel-farm in 1993. At that time the garden has received other treatments.

Since 2009, Traituba's Farm has been changing, the Big House do not have residents anymore, functioning only as support. The structures for animal husbandry are disabled and the horse breeding of Mangalarga Marchador from Traituba's Farm was transferred to the Cruzilia city. Currently the farm has 1050 ha and its main farming is corn field (GARCIA and PAIVA, 2012). The old pastures that dairy cattle and horses were created were replaced by these large crops of corn. With the family's move and the mechanization of production decreased a lot the historical movement of that farm. These changes caused a significant transformation in the landscape. The pastoral model till then present in the farm's history, no longer exists, and what prevails currently is only the picturesque model.

\section{The gardens of Traituba's Farm}

Despite the large representation of power and wealth of Traituba's Farm, it is observed that the gardens never mirrored in models of the imposing French gardens, Italian or English. The great Portuguese cultural influence, origin of the Junqueira's family, transmitted to the gardens one simplicity trait with utilitarian functions, this being associated with vegetable gardens and orchards. Vegetables gardens, exotic fruit trees like mango, avocado, lemon, orange, etc, were grown. They also had medicinal plants, ornamental plants and some flowers were used to decorate the jars inside the Big House. 
In the front yard (1) until the early twentieth century, there were large trees. In the same period, in front of the house, following the main entrance door, there was a sidewalk of large stones and a landscaped garden, which then was all surrounded by wooden slats cut. It is assumed that this garden has always existed, since the house construction. Besides being an attempt to beautification, it would also be a division and boundary between the private quarters of the family and the area where it worked great trade. Still, this surrounded, there was a vegetable garden that was mixed with the garden. Outside of that space was at its entrance a small fountain
(Figure 8). In this garden cultivated a great diversity of species, but without any organization in beds or defined paths. Among the cultivated species, are mentioned Hortensia (Hydrangea macrophylla), Roses (Rosa sp.), Christmas cactus (Schlumbergera truncata), Lacy tree philodendron (Philodendron bipinnatifidum), Sago palm (Cyca revoluta), Crown-of-thorns (Euphorbia milii) grown in cans, and a Palm tree species (Coccothrinax barbadensis) and different species of cacti. There is also some bougainvillea (Bougainvillea sp.), one of which formed an arch at the entrance gate and another covering up an water tank in this garden.

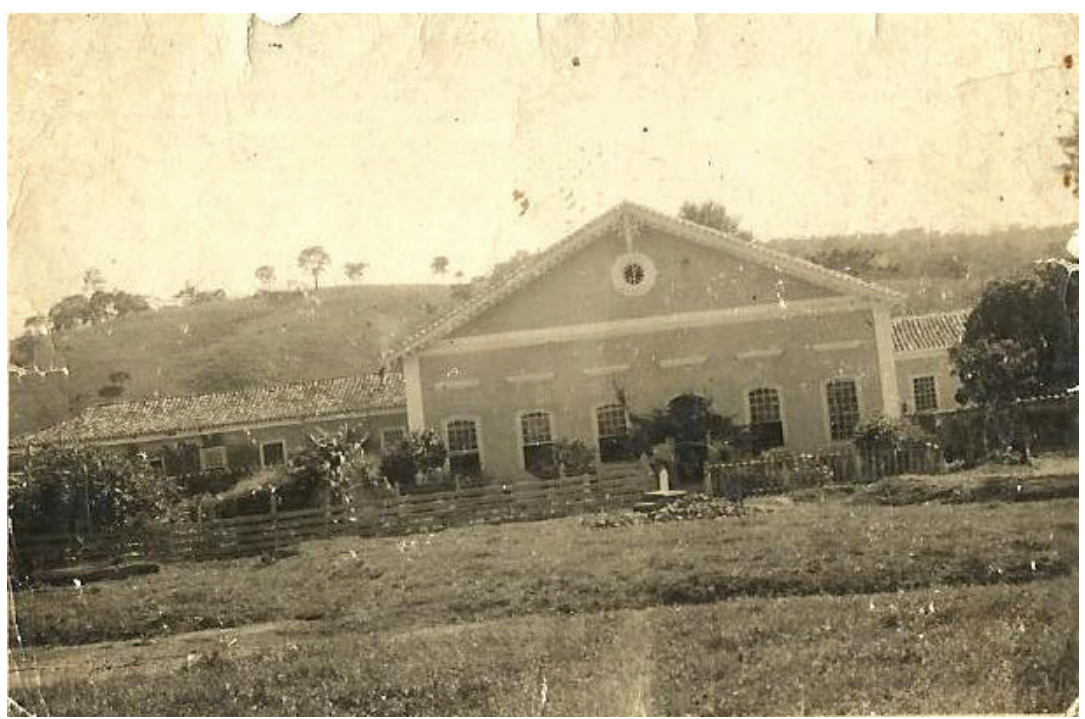

Figure 8. Garden and vegetable garden's entrance before the reform in 1953. Source: Private collection of Junqueira's family

The fountain's presence, this great species diversity, and the lack of organization of the same, remembered the Persian garden style of the Sassanid era, which greatly influenced the Iberians (PAIVA, 2008). Moreover, the fact that the vegetable garden to be the main focus of the entrance garden, emphasizes even more the Portuguese influence (DELPHIM, 2005).

The attention most to the gardens only became to manifest in 1949 with the presence of the owner Alice
Aguiar Junqueira. Her first major intervention was designed and implemented from the 1950s (Figure 9). Alice always had a great appreciation for the gardens' culture and was she who created the greenhouse in that farm, which no longer exists. In her first intervention, the main entrance garden of the farmhouse no longer has utility functions. Her garden was moved to another place. 


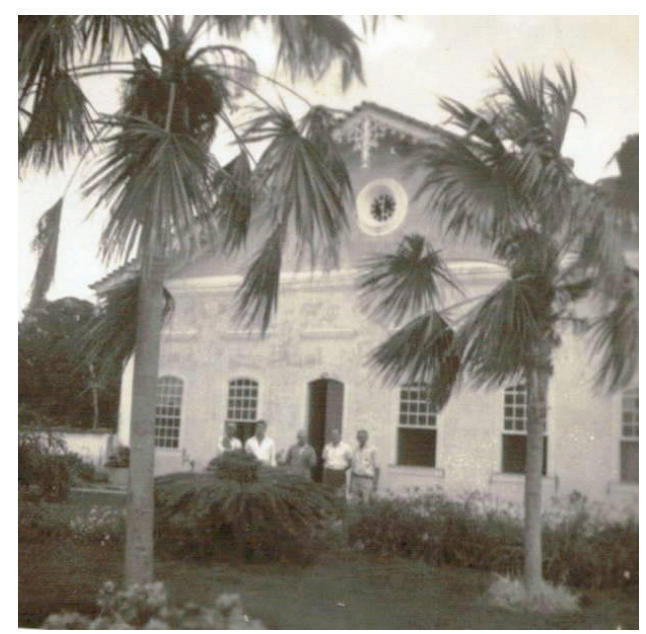

Figure 9. Entrance Garden. Date: 1960s. Source: Private collection of Junqueira's family

The many species found in this garden were arranged in beds structured by some settled cobblestone paths. It was also built a concrete pool and a doll house at the other end of the garden. So, this garden has become a contemplation scenery, home beautification, and family leisure and also for their guests (GARCIA and SALGADO, 2013). But there was no intervention in the old garden, located in the yard 2. This area, after having become stockyard for deer, was almost devoid of plants, leaving only two major jabuticaba tree. As for the main orchard, continued to occupy the same area, outside the boundaries of the wall, place where the vegetable garden that was at the entrance garden was transferred.

In the 1980s, Alice Junqueira feels the need to make a reform in the home just as maintenance, the whole house was painted of blue and white, and other repairs throughout the farmhouse. The renewal of the immense buildings of Traituba's Farm (Figure 10) drew the attention of the Royal Road tourists that began to be interested in the history of the farm.

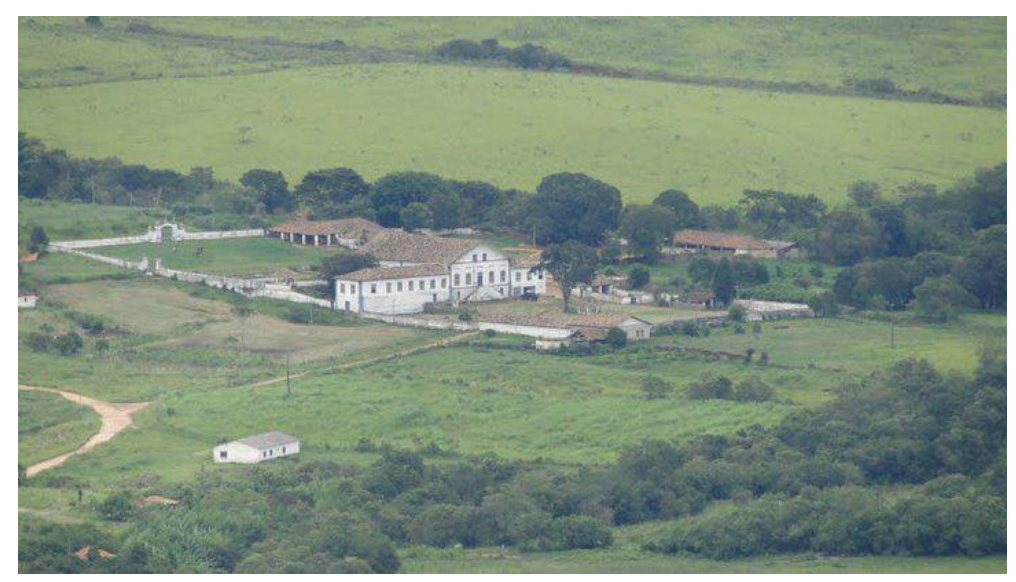

Figure 10. Imposing construction of Traituba's Farm. Source: Private collection of Junqueira's family

From that Alice realized the great economic opportunity and made some improvements to the entrance garden. The pool made of cement was replaced by a glass fiber and its surroundings were built two kiosks with wooden structure, covered in dry grass, serving as a rest area and contemplation. It was also made plant borders for all sidewalks, whose route of the 1950s was maintained. Thus, in 1993, the Traituba's Farm Hotel was inaugurated (Figure 11). The farm operates as a hotel until 2007, when the attention to the garden declined and in 2009 was sold to a group of businessmen, no longer being the traditional Junqueira's family. 


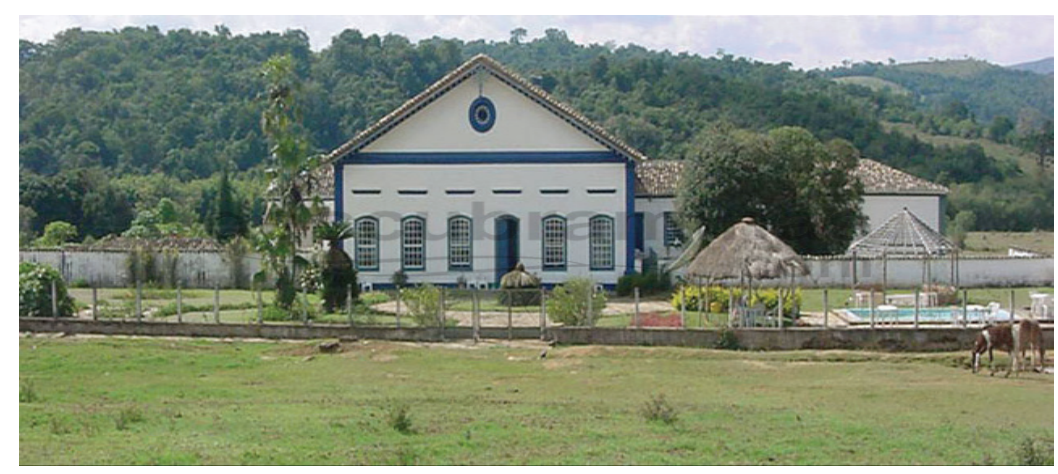

Figure 11. Entrance garden: 1990s. Source: Private collection of Junqueira's family

For about ten years, the entrance garden remained without major changes. In 2004, the farm was again reformed only for the purpose of maintenance and, therefore, some minor changes were also made in this garden. A kiosk was removed and was replaced by another made by brickwork.

The plants found in the garden since the 1950s left Bahiagrass (Paspalum notatum), Hortensia (Hydrangea macrophylla), Roses (Rosa sp), Lacy tree philodendron (Philodendron bipinnatifidum) Sago palm (Cyca revoluta) and Palm tree (Coccothrinax barbadensis). Over time other species have been introduced, and today there are: Hemerocale (Hemerecallis $x$ hybrida), African lily (Agapanthus africanus), Bird-of-paradise flower (Strelitzia reginae), Garden croton (Codiaeum variegatum), Pomegranate (Punica granatum), Azaleas (Rododendum sp.), Heliconia (Heliconia sp), Jungle flame (Ixora coccinea), Purple secretia (Tradescantia pallida var. pupurea), Nandina (Nandina domestica).

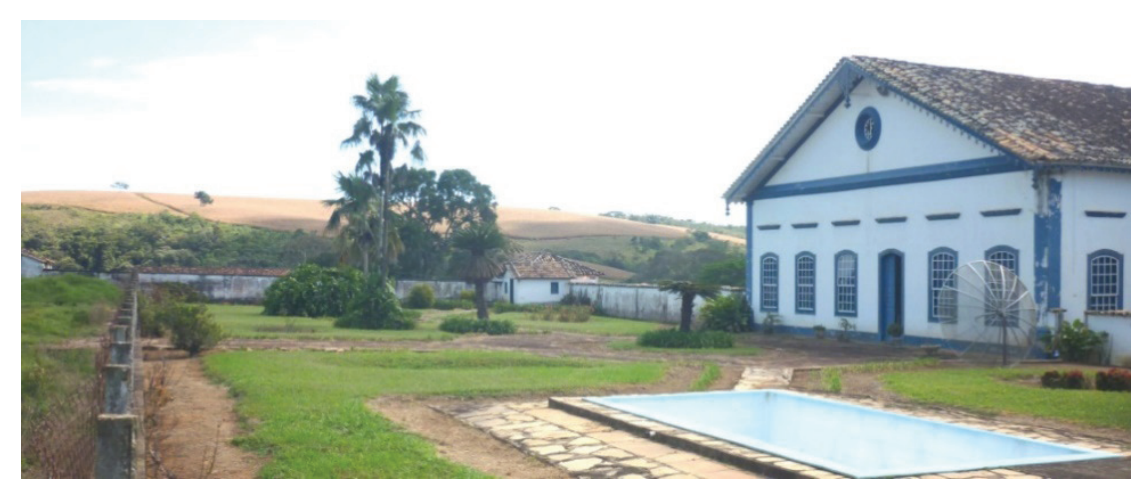

Figure 12. Entrance Garden of Traituba’s Farm. Date: 2013. Source: Garcia

Architectural elements that make up this space do not present good conservation. The garden composition follows a seemingly simple design, with species easy to maintain, and yet receive no special treatment maintenance or revitalization, except for the grass cut.
Currently, the entrance garden appears quite different from the nineteenth century garden. It is still possible to observe the layout and design formed in the $1950 \mathrm{~s}$ (Figure 13). 


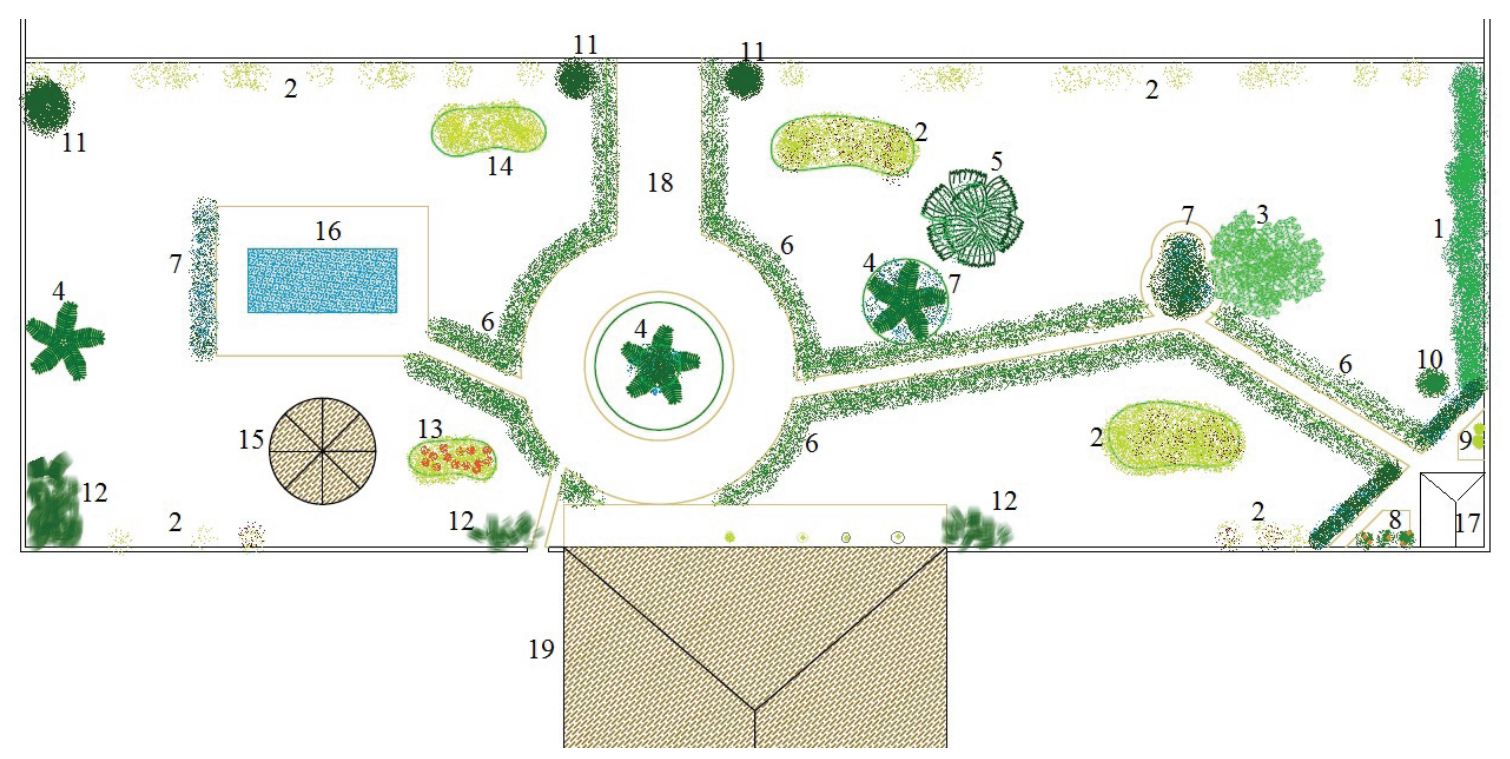

Figure 13. Current representative design of the entrance garden. Subtitle: 1-Hydrangea macrophylla; 2-Rosa sp.; 3-Philodendron bipinnatifidium; 4-Cyca revoluta; 5-Coccothrinax barbadensis;6-Hemerecallis $x$ hybrid;

7-Agapanthus africanus; 8-Strelitzia reginae; 9-Codiaeum variegatum;10-Punica granatum;11-Rododendum sp.; 12-Heliconia sp.;13-Ixora coccinea; 14-Tradescantia pallida var. pupurea; 15-kiosk; 16-swimming pool; 17-Dollhouse; 18-Paths; 19-House. Source: Design made by Garcia 2013

\section{CONCLUSIONS}

A historical look at Traituba's Farm is possible to conclude that in the first decades of existence, the late eighteenth century to the early nineteenth century, the Traituba's Farm was formed by a small ranch, built in the middle to great pastures divided by valleys, hills and small rivers. The farm's landscape before the Big House construction referred to the pastoral model.

This landscape has undergone a major change when the new farmhouse was built from 1827 to 1831 . What once dated back to quiet pastoral landscapes turned into a very busy place due to intense movement generated by the productions, animals and trade that settled there. This change created a new farm landscape model, the bucolic. The grandeur and beauty of the Big House complex also created references to the picturesque landscape.

These models, bucolic and picturesque, lasted for 150 years until the late twentieth century, its intense activities declined, characterizing therefore only a picturesque landscape model. This landscape is made up of its architectural complex, set in large pastures, which also alluded to the pastoral model, model that already featured in the beginning of its history.

The first manifests of gardens in Traituba's Farm are seen in its vegetable gardens and orchard. In front of the house, there was also a landscaped garden and enclosed by wooden slats. Also in this space there is a vegetable garden that was mixed with the garden, with no definition of beds or paths. In this garden a great diversity of species were cultivated, but without any organization in beds or defined paths. This place just underwent changes after 50s, when the vegetable garden was transferred and the garden no longer has utility functions. The various species found in this garden were arranged in beds structured by some settlers stone paths and were also built some architectural elements.

So, this garden has become a contemplation scenery, home beautification, and family leisure and also for their guests. From 1950 until its ascension as Farm Hotel some architectural improvements have been made and some plants were replaced or rearranged. Currently the garden is very different from the original garden of the nineteenth century, so it is possible to see the layout and design formed in the $1950 \mathrm{~s}$, although since then have received no maintenance or needed revitalization.

Despite the large representation of power and wealth of Traituba's Farm, it is observed that the gardens never mirrored in models of the imposing French gardens, Italian or English. Descendants of Portuguese, the owners transmitted to the gardens one simplicity trait with utilitarian functions, this being associated with vegetable gardens and orchards, characteristic of Portuguese's gardens.

This paper has a great relevance due to the historical value of Traituba's Farm, the magnificence of its architectural complex, the peculiarity of its gardens, its exuberant landscapes, and its great representation in regional culture and history. Furthermore, this study has also a great scientific importance, since the results and methodological foundations that have been used here, when analyzing the transformations not only about gardens, but also about the surrounding landscapes, can be used as reference for future researches in this study area. 


\section{AUTHOR CONTRIBUTION}

CSGG performed the research, collected the information, performed the interviews, analysed the data, take the photos, made the figures and wrote the first draft of the manuscript. PDOP helped in development of the idea of the research and in adapting the methodology, performed part of the research, take the photos, as well as critical reading and editing of the manuscript. SFNSCA helped in development of the idea of the research and in adapting the methodology as well as critical reading of the manuscript. MCRS performed the research and collected the information

\section{ACKNOWLEDGMENTS}

The authors are thankful for CNPq, FAPEMIG and CAPES for the financial support and scholarships.

\section{REFERENCES}

ALVES, S.F.N.S.C.; GARCIA, C.S.G.; PAIVA, P.D.O. Transformações físicas e apropriações sociais da Praça Tiradentes em Ouro Preto-MG. Ornamental Horticulture, v.21, p.209-220, 2015.

ALVES, S.F.N.F.C.; FIGUEIREDO, M.A. ; PAIVA, P.D.O. História da Praça Gomes Freire - O Jardim de Mariana. Lavras: EditoraUFLA, 2010. 32p.

ALVES, S.F.N.S.C.; GARCIA, C.S.G.; PAIVA, P.D.O. História da Praça do Largo das Forras - O ponto de encontro de Tiradentes. Lavras: Editora UFLA, 2013, 29p.

AMATO, M. A freguesia de Nossa Senhora da Conceição das Carrancas e sua história. São Paulo: Loyola, 1996. 288 p.

ANDRADE, I.E. Construção e desconstrução do conceito de jardim histórico. Revista de Pesquisa em Arquitetura e Urbanismo, v.8, n.2, p.138-144, 2008.

ANGELIS, B.L.D.; ANGELIS NETO, G. Jardins históricos: introduzindo a questão. Paisagem Ambiente: ensaios, n.19, p.31-48, 2004.

BOXER, C.R. A fonte de ouro do Brasil. São Paulo: Nacional, 1963. 369p.

BRUNO, E.S. História do Brasil (geral e regional). São Paulo: Cultrix, 1967, 2a ed., v.4, 262p.

CARVALHO, F.A. Memória toponímica de Saint-Hilaire pelo caminho velho da estrada real. Letras \& Letras, v.26, n.1, p.185-196, 2010.
CRUZ, C.F. Fazendas do Sul de Minas. Brasília: Iphan/ Programa Monumenta, 2010. 354p.

DELPHIM, C.F.M. Intervenção em jardins históricos: manual. Brasília: IPHAN, 2005. 152p.

GARCIA, C.S.G.; PAIVA, P.D.O.; ALVES, S.F.N.S.C.; SALGADO, M.C.R.; PAIVA, R. The historic Traituba Farm in the XIX century: cultural and economical focus of landscape transformations. Acta Horticulture. v.1108. p. 261-267, 2014.

GARCIA, C.S.G.; ALVES, S.F.N.S.C.; PAIVA, P.D.O. História do jardim da avenida Tancredo Neves - a praia de São João del-Rey. Lavras: Editora UFLA, 2011, 35p.

GARCIA, C.S.G.; PAIVA, P.D.O. Entrevista com Valdir Carlos da Silva na Fazenda Traituba, Cruzília-MG. Dezembro de 2012.

GARCIA, C.S.G.; SALGAGO, M.C.R.; Entrevista com Alice Aguiar Junqueira. Cruzília-MG. Janeiro 2013.

HOLANDA, S.B. Raizes do Brasil. São Paulo: Companhia das Letras, 1995. ed.26. 220p.

JUSTE, L.C.; PAIVA, P.D.O. Resgate histórico da praça da Basílica de Bom Jesus de Matosinhos em Congonhas, Minas Gerais. Ornamental Horticulture, v.21, p.63-76, 2015.

LASSUS, B. L'obligation de I'inventio: du paysage aux ambiances successives. In: BERQUE (Dir.). Cinq propositions pour unethéorie du paysage. Paris: Champ Vallon, 1994

LOPES, L.N. História das fazendas tradicionais da Estrada Real. Belo Horizonte: Top 2000, 2012. 240p.

LUGINBUHL, Y. Paysage et identification, qualification et objectifs de qualités. In: Paysage et développement durable: les enjeux de la convention européenne du paysage. Strasbourg: I'Europe, 2006.

LUGINBHUL, Y. Paysages: textes et représentation du paysage du sièle des LUMIÈRES à nos jours. Lyon: La Manufacture, 1989. 268 p.

MATTOS, J.A.J. Família Junqueira: sua história e genealogia. Rio de Janeiro, 5v., 2000p., 2004.

PAIVA, P.D.O. Paisagismo - Conceitos e aplicações. Lavras: Editora UFLA, 2008, 608p. 
PAIVA, P.D.O.; NASCIMENTO, A.M.P. História da Praça Barão de Queluz - o caminho para o ouro em Conselheiro Lafaiete. Lavras: Editora UFLA, 2012, 35p.

SAINT-HILAIRE, A. Segunda viagem a Minas Gerais e São Paulo. São Paulo: Nacional, 1938.
SILVA, A.T.; TAVARES, T.S.; Paiva, P.D.O.; NOGUEIRA, D.A. As praças Dr. Augusto Silva e Leonardo Venerando Pereira, segundo a visão dos seus frequentadores. Ciência e Agrotecnologia, v.32, p.1701-1707, 2008.

VASCONCELLOS, S. Vila Rica: formação e desenvolvimento; residências. São Paulo: Perspectiva, 1977. $121 \mathrm{p}$. 